\title{
MENAKAR PENGAWASAN PEMBERIAN BANTUAN HUKUM DALAM PANDANGAN RICHARD A POSNER
}

(Control Measure Granting Legal Aid Views of Richard A Posner)

\author{
Muhammad Rustamaji \\ Fakultas Hukum Universitas Sebelas Maret (UNS) Solo \\ Jalan Ir. Sutami 36A Kentingan Jebres Surakarta \\ Email: hatchi_ajie@yahoo.com
}

Naskah diterima: 22 April 2013; revisi: 24 April 2013; disetujui: 26 April 2013

\begin{abstract}
Abstrak
Kajian hukum yang dilakukan bertujuan menakar pengawasan pemberian bantuan hukum dalam pandangan teori hukum Richard A Posner. Pendekatan economy analysis of law yang dikemukakan Posner, dijadikan pisau analisis guna membedah pola pengawasan pemberian bantuan hukum yang dimanatkan undang-undang. Metode penelitian yang digunakan menggombinasikan ilmu hukum sebagai ilmu atau disiplin yang hermeneutik, argumentatif, dan disiplin empiris. Hasil penelitian mengenai pembedahan pengawasan pemberian bantuan hukum dengan pisau analisis teori hukum Richard A. Posner menunjukkan bahwa efisiensi aturan hukum yang ditujukan mewujudkan kesejahteraan sosial dan keadilan, memerlukan prinsip ekonomi yang kemudian masuk dalam ranah hukum. Konsep hukum yang mensejahterakan coba dibuktikan pada perwujudan pengawasan atas bantuan hukum yang diberikan kepada masyarakat miskin. Lima aspek yang menyusun teori hukum Posner menunjukkan bahwa kelindan hukum dan ekonomi merupakan keniscayaan yang nyata.

Kata kunci: Posner, Bantuan Hukum, Pengawasan
\end{abstract}

\begin{abstract}
Research purposes to measure the oversight of legal assistance in view of the legal theory Richard A. Posner. Economy analysis of law approach proposed Posner, used a knife to dissect the analysis of patterns of supervision duty legal aid legislation. The method used combine jurisprudence as a science or a hermeneutic discipline, argumentative, and empirical discipline. The results of the surgical control of legal assistance with legal theory analysis knife Richard A. Posner suggests that the efficiency of legal rules aimed at social welfare and justice, requires economic principles which later entered the realm of law. The concept of welfare laws trying to prove to the realization of control over legal aid given to the poor. Five aspects that make up the legal theory linked by Posner suggests that law and economics is a real necessity.
\end{abstract}

Keywords: Posner, legal aid, supervision 


\section{A. Pendahuluan}

Sebagai negara yang dipersepsikan memedomani civil law, kajian terhadap produk hukum yang telah diatur dalam kodeks menjadi penting dilakukan untuk memberikan penilaian kritis. Sehingga, telaah atas produk perundangan demikian tidak hanya dilihat sebagai hasil kerja profesional, tetapi sebagaimana pandangan Satjipto Rahardjo, sebagai objek ilmu ${ }^{1}$ untuk menjelaskan bahwa produk hukum yang terkodivikasi dalam undang-undang sekalipun, bukan merupakan sesuatu yang sakral untuk diuji persistensi ataupun kadarnya.

Mengerucut pada keterlibatan negara dalam percepatan aksesibilitas hukum sesuai amanat undang-undang, isu hukum demikian menemukan momentumnya ketika UndangUndang Bantuan Hukum hadir sebagai jaminan terhadap keadilan dan kesamaan di hadapan hukum. Dengan berasaskan efisiensi yang memaksimalkan pemberian bantuan hukum melalui penggunaan sumber anggaran yang ada, pada saat bersamaan memunculkan asas akuntabilitas ${ }^{2}$, yaitu bahwa setiap kegiatan dan hasilakhirdarikegiatanpenyelenggaraanbantuan hukum harus dapat dipertanggungjawabkan kepada masyarakat. Pada titik inilah tesis Richard A Posner mengenai biaya transaksi ${ }^{3}$ (transaction costs) ${ }^{4}$ yang kemudian diadopsi ke dalam aturan-aturan legal, menemukan kelindannya. Biaya transaksi yang semula merupakan prinsipprinsip ekonomi, pada tataran kekinian ternyata justru dijadikan aturan-aturan hukum.
Meskipun pemberian Bantuan Hukum tidak secara tegas dinyatakan sebagai tanggung jawab negara, namun sebagai negara hukum yang mendasarkan diri pada ketentuan Pasal 1 ayat (3) Undang-Undang Dasar Negara Republik Indonesia Tahun 1945, peran dan tanggungjawab aksesibilitas demikian diambil oleh negara. Sebagai negara hukum, Indonesia mengakui dan melindungi hak asasi manusia bagi setiap individu termasuk hak atas bantuan hukum. Penyelenggaraan pemberian bantuan hukum kepada warga negara merupakan upaya untuk memenuhi dan sekaligus sebagai implementasi negara hukum yang mengakui dan melindungi serta menjamin hak asasi warga negara akan kebutuhan akses terhadap keadilan (access to justice) dan kesamaan di hadapan hukum (equality before the law) $)^{5}$. Untuk itu ketika anggaran negara dialokasikan guna menjamin warga negara, khususnya bagi orang atau kelompok orang miskin untuk mendapatkan akses keadilan dan kesamaan di hadapan hukum, pengawasan menjadi kata kunci untuk menjamin keberhasilannya.

Berkaitan dengan pola hubungan pengawasan dengan tujuan pemberian bantuan hukum dimaksud, penekanan pandangan Posner dalam teori hukumnya adalah mengenai efisiensi yang terarah pada social welfare dan good law. Prinsip efisiensi ini terutama berada dalam lingkup prinsip-prinsip ekonomi yang senantiasa dialami manusia sebagai subjek hukum setiap harinya. Sehingga, sesuai dengan prinsip awal

1 Satjipto Rahardjo, "Mengajarkan Keteraturan Menemukan Ketidakteraturan (Teaching Order Finding Disorder)" (makalah disampaikan pada Pidato Mengakhiri Masa Jabatan Sebagai Guru Besar Tetap pada Fakultas Hukum, Universitas Diponegoro, Semarang, 15 Desember 2000).

2 Penjelasan Pasal 2 huruf d dan f Undang-Undang Nomor 16 Tahun 2011 tentang Bantuan Hukum, hlm. 14.

3 Adi Sulistiyono dan Muhammad Rustamaji, Hukum Ekonomi Sebagai Panglima, (Sidoarjo: Masmedia Buana Pustaka, 2009), hlm. 19.

4 Ahmad Erani Yustika, Ekonomi kelembagaan, Definisi, Teori, \& Strategi, (Malang: Bayumedia Publishing, 2006).

5 Penjelasan Umum Undang-Undang Nomor 16 Tahun 2011 tentang Bantuan Hukum, hlm. 12. 
berkembanganya economy analysis of law ${ }^{6}$ atas gagasan Posner demikian, kajian lebih dalam patut dilakukan.

\section{B. Permasalahan}

Permasalahan yang diangkat sebagai fokus isu hukum dalam artikel dimaksud, hanya dikerucutkan pada bagaimana teori hukum Richard A Posner menakar pengawasan bantuan hukum dalam pendekatan economy analysis of law. Hal ini kemudian dirumuskan dengan beberapa pertanyaan berikut:

1. Bagaimana aspek heuristic dan descriptive dalam bangunan teori hukum Richard $A$ Posner?

2. Bagaimana aspek sejarah utilitarianisme dalam bangunan teori hukum Richard $A$ Posner?

3. Bagaimana aspek wealth maximization dalam bangunan teori hukum Richard $A$ Posner?

4. Bagaimana aspek pertimbangan masa depan dalam bangunan teori hukum Richard A Posner?

5. Bagaimana aspek behaviorial law and economy dalam bangunan teori hukum Richard A Posner?

\section{Metode Penelitian}

Mark Van Hoecke, mengemukakan ada beberapa konsep doktrin hukum atau ilmu hukum, antara lain: ${ }^{7}$ a. Disiplin hermeneutik (hermenuetic discipline), b. Disiplin argumentatif (argumentative discipline), c. Disiplin empiris (empirical discipline), d. Disiplin eksplanatoris (explanatory discipline), e. Disiplin aksiomatik (axiomatic discipline), f. Disiplin logis (logical discipline), dan g. Disiplin normatif (normative discipline). Berbagai disiplin doktrin hukum itu memiliki implikasi metodologis yang sangat berbeda. Sehubungan dengan pembedaan itu, maka penelitian dimaksud menggombinasikan ilmu hukum sebagai ilmu atau disiplin yang hermeneutik, argumentatif, dan disiplin empiris. ${ }^{8}$

Dengan memilih ketiga displin dalam doktrin ilmu hukum, maka penelitian ini mempunyai lebih dari satu dimensi. ${ }^{9}$ Artinya, penelitian ini mengkombinasikan pendekatan doktrinal dan nondoktrinal. Hal tersebut seperti diungkapkan Mike McConville dan Wing Hong Chui, yaitu "to generate empirical evidence to answer research questions". ${ }^{10}$ Pendekatan doktrinal didasarkan pada bahan hukum primer dan bahan hukum sekunder, seperti dalam pandangan Peter Mahmud Marzuki ${ }^{11}$.

6 Richard A. Posner, Economic Analysis of Law, Ed. 4 (USA: Harvar University Press, 1994), hlm. 4.

7 Mark van Hoecke, "Legal Doctrine: Which Method(s) for What Kind of Discipline? In Mark Van Hoecke (ed.), Methodologies of Legal Research, Which Kind of Method for What Kind of Discipline" (Oxford: Hart Publishing, 2011), hlm. 1-18 dan hlm. 4-10.

8 Menurut Hoecke, disiplin ilmu hukum yang bersifat hermeneutik, teks dan dokumen hukum merupakan sumber utama dari objek penelitian. Kegiatan utama yang dilakukan oleh peneliti adalah menginterpretasi teks dan dokumen menurut metode standar interpretasi. Sedangkan disiplin yang bersifat argumentatif digunakan untuk mendukung interpretasi hukum atau mendukung penyelesaian masalah yang telah ditekankan oleh peneliti. Sebagai disiplin empirikal menekankan bahwa dalam penelitian doktrinal itu juga harus disebut sebagai "empirical social science". Sehingga, verifikasi empiris dilakukan juga untuk membuktikan (checking) pernyataan dalam doktrin hukum jika dihadapkan dengan praktek judisial. (Ibid.)

Ibid.

10 Mike McConville dan Wing Hong Chui, (Ed.), Research Method for Law (Edinburgh: Edinburgh University Press, 2007), hlm. 80.

11 Peter Mahmud Marzuki, Penelitian Hukum (Jakarta: Kencana Prenada Media Group, 2005), hlm. 141. 


\section{Pembahasan}

Guna melisik simulakrum teori hukum Richard A Posner ketika dijadikan instrumen gu- economy analysis of law. Guna memberikan gambaran yang komperhensif dalam pembahasan, berikut disampaikan skematik bahasan.

Gambar 1. Skematik Pembedahan Pengawasan Bantuan Hukum Berdasar Teori Hukum Posner

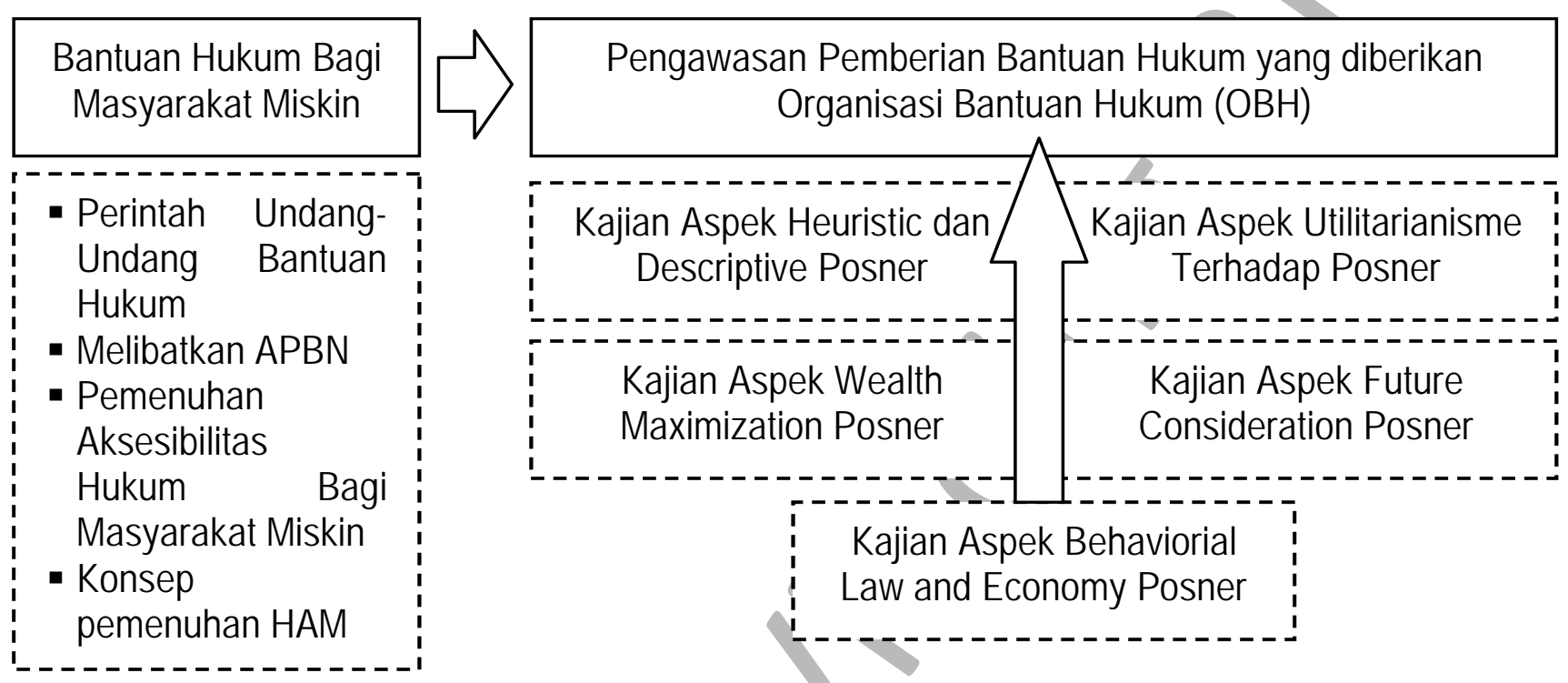

Sumber: Diolah sendiri berdasar teori Posner

na menakar pengawasan bantuan hukum dalam pendekatan economy analysis of law, langkah pembahasan perlu dilakukan dalam beberapa tahap. Pada bagian awal bahasan diarahkan pada rangkaian akar teori yang melandasi pemikiran hukum Richard A Posner. Kajian teoritik Posner berkait latar belakang seorang hakim serta rangkaian proses persidangan yang menimbang pihak-pihak yang berhadapan di muka hukum demikian, tidak terlepas dari praktik bantuan hukum yang diberikan seorang advokat. Kajian bantuan hukum dalam interaksi proses persidangan demikian merupakan bahan baku yang berharga untuk membedah efisiensi hukum yang acapkali dikumandangkan Posner. Berdasarkan teori hukum Posner demikian, kajian selanjutnya difokuskan pada indikator pemenuhan takaran terhadap pola pengawasan bantuan hukum yang diukur melalui pendekatan

\section{Kajian Aspek Heuristic dan Descriptive dalam Bangunan Teori Hukum Richard A Posner}

Richard A. Posner menegaskan terdapat banyak teori positif (yaitu deskriptif, yang berbeda dengan normatif) mengenai perilaku pengadilan (judicial behavior). Posner mengemukakan teori-teori yang lebih kompleks, meliputi : (1) attitudinal, (2) strategis, (3) sosiologis, (4) psikologis, (5) ekonomi, (6) organisasional, (7) pragmatis, (8) fenomenologis, dan (9) legalis. Semua teori memiliki manfaat dan memberi nutrisi pada teori putusan pengadilan yang dibangun oleh Posner. Namun, semuanya berlebihan atau tidak lengkap. Posner sendiri membangun teori yang disebutnya dengan "a positive decision theory of judging" (teori penilaian putusan 
yang positif). ${ }^{12}$ Konstruksi Posner itu hendak memulai ulang dan memurnikan teori-teori yang ada- yaitu sesuatu yang meyakinkan (cogent), menyatukan (unifed), realistik dan tepatnya beragam (eclectic) mengenai bagaimana hakim sampai pada putusannya dalam kasus-kasus yang tidak rutin. Posner menganggap perilaku pengadilan sebagai"open area"-suatu area yang menjadikan hakim sebagai legislator (judge is a legislator). ${ }^{13}$ Teorisasi Posner ini dilatarbelakangi karakter penghakiman di Amerika. Meski demikian, secara teoritis tetap memiliki signifikansi untuk dipergunakan, sekaligus diuji kebenarannya dalam "laboratorium" hukum, seperti Indonesia. Urgensi pengujian demikian semakin lengkap terlebih ketika ditumbukkan dengan pertimbangan hakim atas bantuan hukum yang tentu membentuk alur maupun konstruksi tersendiri dalam dinamisasi diskursus proses peradilan.

Pada sekup ekonomi yang lebih sempit, sebagai penganut normative directive, Posner mengemukakan bahwa hukum seharusnya mempromosikan efisiensi dan menggunakan analisis social wealth maximization untuk mencari sintesis theoremanya. Melalui kajian dalam bukunya yang bertajuk "Frontiers of Legal Theory", Posner meneliti aspek heuristic dan descriptive dari analisis ekonomi dalam hukum. Aspek heuristic ingin mengkaji kesatuan antara doktrin hukum dengan institusi hukum. Sementara aspek descriptive berusaha mencari logika ekonomi yang memengaruhi doktrin dan institusi hukum hingga mengakibatkan perubahan hukum. ${ }^{14}$
Mencermati hubungan doktrin hukum terhadap institusi hukum berkait bantuan hukum dan pengawasannya, pola demikian dapat dijelaskan melalui aspek heuristic Posner. Dalam perspektif hukum pidana misalnya, ketika doktrin hukum menasbihkan equality before the law ${ }^{15}$ secara imperatif berlaku bagi setiap orang yang berhadapan dengan hukum, muncul pertanyaan bagaimana kedudukan tersangka/ terdakwa terhadap institusi penegak hukum?. Jika benar selama ini tersangka/terdakwa kedudukannya setara dengan penyidik maupun penuntutumumkarenaberlakunyaasasakusatur, lalu mengapa advokat masih diperlukan guna memberikan bantuan hukum? Disinilah terlihat bahwa doktrin hukum saja tidaklah cukup tanpa institusi hukum bentukan yang difungsikan untuk menopangnya. Doktrin hukum yang menempatkankesetaraankedudukantersangka/ terdakwa ketika berhadapan dengan hukum ternyata masih menyisakan ketimpangan yang lebih bersifat empiris. Pengetahuan hukum, aksesibilitas terhadap dunia hukum, persamaan hak di hadapan hukum, menjadi beberapa indikator ketimpangan dimaksud.

Lalu ketika ketimpangan doktrin demikian coba diseimbangkan dengan institusional bantuan hukum utamanya bagi kaum papa melalui perundangan, pola relasi doktrin dan institusi demikian semakin menunjukkan kesejatiannya. Dengan beragam format bantuan hukum mulai dari konsultasi, pendampingan hukum nonlitigasi, advokasi, hingga penguasaan hukum diranah litigasi posisi berimbang subyek hukum tersangka/terdakwa semakin terlihat. Pada titik ini, pewujudan hukum dengan pola

\footnotetext{
12 Richard A. Posner, How Judges Think (Cambridge: Harvard University Press, 2008), hlm. 19.

13 Ibid., hlm. 15.

14 Richard A. Posner, Frontiers of Legal Theory (USA: Harvard University Press, 1994).

15 Penjelasan Umum Undang-Undang Nomor 8 Tahun 1981 tentang Hukum Acara Pidana (KUHAP).
} 
kesetimbangan kedudukan yang equal antara tersangka/terdakwa yang dilengkapi bantuan hukum dari advokat, terhadap posisi aparat penegak hukum, sudah memunculkan nilai ekonomi yang harus terbayar.

Oleh karenanya, ketika nilai ekonomi demikian muncul sebagai sesuatu yang tidak terhindarkan, payung hukum harus meresponnya dengan doktrin hukum yang lain. Inilah yang kemudian membawa negara dengan perencanaan keuangannya harus mengcover kebutuhan bantuan hukum secara efektif dan akuntabel. Di sisi inilah pengawasan berperan penting untuk menjaga kesetimbangan relasi bantuan hukum tetap berjalan sesuai peruntukannya. Pengawasan yang longgar, membuka celah baru tidak hanya terjadinya penyelewengan pemanfaatan uang negara, namun mengorbankan pula harapan aksesibilitas hukum yang setara bagi sang jelata.

Adapun mengenai aspek descriptive yang berusaha mencari logika ekonomi yang memengaruhi doktrin dan institusi hukum hingga mengakibatkan perubahan hukum, ternyata juga dapat diketemukan muaranya pada pandangan Posner. Harga untuk menjaga konsistensi sebagai negara hukum yang melindungi seluruh rakyatnya sebagaimana tertuang dalam konstitusi, tentu relatif murah jika diperbandingkan dengan pengalokasian sejumlah dana kepada kementerian terkait dalam upayanya menutup kebutuhan bantuan hukum yang diperlukan. Tetapi dengan spektrum yang luas dengan sebaran masyarakat yang kurang beruntung di bidang ekonomi, tentu permasalahan anggaran mengkondisikan untuk dilakukannya penyiasatan untuk memenuhi kebutuhan bantuan hukum bagi warga miskin dimaksud. Untuk itulah dilakukan supervisi, visitasi, dan bahkan akreditasi organisasi bantuan hukum $(\mathrm{OBH})$ yang memiliki kualifikasi tinggi dalam memberikan bantuan hukum bagi masyarakat miskin. Langkah demikian tentu merupakan strategi yang tidak hanya memenuhi logika ekonomi, namun dalam waktu bersamaan diharapkan menjamin kualitas bantuan hukum yang diberikan kepada yang membutuhkan. Pola pengawasan dan kontrol demikian selanjutnya bergulir sesuai dengan tata aturan pemanfaatan keuangan negara, bagi siapapun penggunanya. Artinya pengawasan pasca akreditasi berkait pemanfaatan uang negara juga dilakukan sebagai wujud akuntabilitas atas efisiensi dan efektifitas permodelan bantuan hukum yang dijalankan.

Pada perspektif inilah Pasner menginkan suatu kebijaksanaan dalam memutuskan suatu perkara yang didalamnya terjadi dialektika yang masif antara aparat penegak hukum dengan para pakar hukum lain (hakim dan advokat) dalam suasana persidangan yang mencerahkan. Oleh karena itu, suatu kasus harus dilakukan anotasi atau bahkan eksaminasi yang tidak hanya diambil dari sudut hukum tradisional praktis atau pun teori legal an sich, akan tetapi lebih dari itu, segala aspek di luar hukum harus dipertimbangkan ${ }^{16}$.

\section{Kajian Aspek Sejarah Utilitarianisme dalam Bangunan Teori Hukum Richard A Posner}

Membuka kembali beragam kajian teoritik atas hukum, dapatlah diketahui bahwa Posner bukanlah pionir yang menelurkan 
buah gagasan mengenai economy analysis of law. Teori dimaksud sejatinya telah terlebih dahulu muncul dan dieksplorasi oleh kalangan utilitarianisme dengan tokohnya Jeremy Bentham dan John Stuarth Mill. Teori utilitas ini mengutamakan asas kebergunaan sesuatu. Jadi sesuatu (esse) harus memberikan manfaat (nilai utilities) bagi esse yang lain (social welfare $)^{17}$. Dalam perkembangannya, setelah dianalisis kembali oleh Ronald Coasei (1960) dan Posner, ide analisis ekonomi dalam hukum berkembang mencakup transaction cost of economy, economy institution, dan public choice. Transaction cost of economy berkaitan dengan efisiensi peraturan hukum yang sebagian besar berkenaan dengan hukum privat. Economy Institution berkaitan dengan tindakan manusia termasuk peraturan hukum formal, kebiasaan informal, tradisi dan aturan sosial. Serta Public Choice berkaitan dengan proses memutuskan secara demokratis dengan memertimbangkan metode microeconomy dan perdagangannya ${ }^{18}$. Melalui prinsip ekonomi, Posner berharap dapat meningkatkan efisiensi hukum, termasuk efesiensi dalam meningkatkan kesejahteraan sosial.

Pada konsteks implementasi pengawasan pemberian bantuan hukum, langkah paling ekonomis dengan menseleksi terlebih dahulu kredibilitas organisasi bantuan hukum merupakan perwujudan cakup transaction cost of economy, economy institution, dan public choice.

Berkenaan dengan kaitan efisiensi peraturan hukum yang berkelindan dengan hukum privat, hubungan antara sang klien dengan advokat menjadi target pengawasan. Ketika advokat bekerja secara profesional membela hak sang klien, maka ia berhak atas pembayaran berwujud legal service fee yang sepadan. Masalah muncul ketika sang klien ternyata orang yang terkategorisasi miskin. Tantangan pengawasan yang dihadapi kemudian adalah bagaimana di satu sisi sang advokat tetap bekerja profesional membela hak sang klien, melaporkan pengeluaran yang wajar tanpa rekayasa, untuk selanjutnya tertib dalam mekanisme penggantian dana bantuan hukum berdasarkan perintah undangundang oleh negara. Sementara di sisi yang lain bagaimana menjamin sang advokat btetap berlaku dan bertindak santun dan profesional memperlakukan klien yang notabene miskin, ketika seluruh waktu, upaya dan pemikiran yang dicurahkan ia tanggung sendiri karena memang belum mendapatkan penggantian?. Pada cek poin inilah pengawasan memiliki peran penting mengungkap judicial behavior yang mencakup legal (legal), attitudinal (attitudinal), dan strategis (strategic). ${ }^{19}$

Adapun mengenai economy institution yang berkaitan dengan tindakan manusia termasuk peraturan hukum formal, kebiasaan informal, tradisi dan aturan sosial, peran pengawasan tidak kalah menariknya. Pemilihan organisasi bantuan hukum yang kredibel sejatinya memangkas keraguan atas potensi penyimpangan atas tindakan pemberi bantuan hukum terhadap peraturan hukum formal, kebiasaan informal, tradisi dan aturan sosial. Organisasi bantuan

\footnotetext{
17 Erman Radjagukguk, FilsafatHukum (Modul Kuliah) (Jakarta: Universitas Indonesia, 2011).

18 Ibid., hlm. 146.

19 Lawrence Baum, Judges and Their Audiences, A Perspective on Judicial Behavior (Princeton and Oxford, Princeton University Press, 2006), hlm. 5.
} 
hukum yang terakreditasi memang tidak serta merta kehilangan ijin beracaranya ketika mengabaikan profesionalisme pemenuhan di bidang peraturan hukum formal, kesantunan tradisi, aturan sosial maupun kebiasaan informal. Namun organisasi bantuan hukum yang kredibel tentu akan menimbang dan membanding untuk tidak taat atas tuntutan profesi yang dihadapkan kepadanya. Pencitraan dan pertaruhan nama besar organisasi bantuan hukum menjadi 'perjudian' yang terlalu mahal untuk 'dipertaruhkan secara murah' dengan bertindak tidak profesional. Pada cek poin inilah nilai keekonomian sebuah institusi berkait erat dengan predikat officium nobile yang disandangkan pada profesi advokat pemberi bantuan hukum.

Pada sisi public choice yang berkaitan dengan proses memutuskan secara demokratis dengan mempertimbangkan metode microeconomy dan perdagangannya, tantangan pengawasan dihadapkan pada proses bantuan hukum di dalam peradilan. Pada proses demikian hukum diarahkan menjadi efisien karena dialektika hukum dalam proses peradilan tidak tersendat akibat ketidaktahuan aturan formal maupun material yang belum tentu dikuasai oleh sang klien. Keseluruhan pembahasaan hukum dalam hal ini dijembatani oleh penasihat hukum demi membela hak klien. Adapun putusan hakim meskipun tetap independen dan imparsial, diharapkan tetap memertimbangkan kajian hukum yang meringankan diri klien, pasca diperjelas dengan eksistensi bantuan hukum bagi klien dimaksud. Pada saat bersamaan, pendampingan hukum maupun bantuan hukum yang dirasakan masyarakat miskin yang berhadapan dengan hukum, memberikan sebuah pengalaman empiris serta pemberdayaan yang meningkatkan efesiensi proses hukum dan peningkatan kesejahteraan sosial yang bersangkutan.

\section{Kajian Aspek Wealth Maximization dalam Bangunan Teori Hukum Richard A Posner}

Wealth Maximization sebagai sebuah pengejawantahan teori analisis ekonomi dalam hukum Posner, sebenarnya menfokuskan diri pada penerapan prinsip efisien. Dalam hal ini Posner menterjemahkan efisien sebagai suatu keadaan yang sumber dayanya dialokasikan sehingga nilainya (value) maksimal. Dalam analisis ekonomi, efisiensi dalam hal ini difokuskan kepada kriteria etis dalam rangka pembuatan keputusan-keputusan sosial (social decision making) yang menyangkut pengaturan kesejahteraan masyarakat ${ }^{20}$. Pada pembicaraan pemberian bantuan hukum dimaksud, welalth maximization terletak pada tepatnya ide serta gagasan yang muncul dari pembentuk undangundang untuk memikirkan perlunya mengcover kebutuhan akan aksesibilitas terhadap hukum yang berkesetaraan. Namunakibatperbandingan kebutuhan bantuan hukum yang sangat besar tidak dapat dipenuhi dengan sumber daya yang saat ini ada, maka pilihan efisiensi harus diberlakukan. Pengawasan pemberian bantuan hukum inilah yang kemudian menjadi key words demi tercapainya kesetimbangan kebutuhan dan sumber daya yang ada. Tanpa pilihan efisiensi berupa pengawasan, maka tujuan menyeimbangkan posisi masyarakat miskin yang berhadapan dengan hukum,

20 Richard A. Posner, Economic Analysis of Law, Ed. 4, (USA: Harvar University Press, 1994), hlm. 4. 
pada akhirnya akan tumbang. Dengan lain perkataan, penyeimbangan yang yang direalisasi dengan bantuan hukum, harus disenantiasa dikontrol dengan pengawasan yang efisien. Oleh karenanya, efisiensi dalam kaca mata Posner sangat berkaitan dengan peningkatan kekayaan seseorang (sang klien miskin) tanpa mengakibatkan kerugian bagi pihak lain (sang advokat pemberi bantuan hukum).

Berkaitan dengan paparan sebelumnya, analisis ekonomi dalam hukum seperti yang dikenal dengan ide wealth maximization ${ }^{21}$ yang mengkondisikan perubahan aturan hukum dapat meningkatkan efisiensi jika keuntungan pihak yang menang melebihi kerugian pihak yang kalah. Pada tahapan selanjutnya, pihak yang menang dapat memberikan kompesasi kerugian bagi pihak yang kalah sehingga pihak yang kalah tersebut tetap menjadi lebih baik. Dalam konteks ini, Posner menilik salah satu segi keadilan yang mencakup bukan sekadar keadilan distributif dan korektif. Posner menekankan "pareto improvement" yang dalam hal ini tujuan dari pengaturan hukum dapat memberi masukan berharga bagi keadilan dan kesejahteraan sosial ${ }^{22}$.

\section{Kajian Aspek Pertimbangan Masa Depan dalam Bangunan Teori Hukum Richard A Posner}

Selain aspek keadilan, Posner juga memberikan perhatian yang besar berkait aspek masa depan (future consideration) dalam teorinya mengenai hukum. Posner yakin bahwa melalui sistem-sistem ekonomi, pertimbangan mengenai suatu masa depan kesejahteraan sosial akan sangat besar. Dengan begitu, aturanaturan hukum termasuk teori-teori hukum harus mampu dimengerti oleh hakim demi terselenggaranya suatu sistem hukum yang baik. ${ }^{23}$ Hakim dalam porsinya yang besar sangat menentukan putusan yang akan dijatuhkan berdasarkan pertimbangan dan diskursus per kasus yang ditanganinya. Aspek kesejahteraan sosial yang dituju dengan beragam sistem ekonomi yang menunjangnya secara langsung maupun tidak memerlukan kerumpilan aturanaturan hukum dan teori hukum yang saling berkelindan bahkan bersilang sengkarut, dan menuntut hakim untuk dapat membaca dan memahaminya secara komperhensif. Langkah bantuan hukum inilah yang berperan pula dalam pembentukan legal standing hukum hakim yang diperlukan sebelum menjatuhkan putusan dengan ketukan palu keadilan.

Keruwetan dan rumpilnya beragam aturan yang dihadapi hakim di masa-masa yang akan datang memunculkan sebuah pertanyaan kritis dalam dialog di Duke Law Class. Posner menegaskan bahwa seorang hakim harus rajin membaca dan mengupdate informasi seputar hukum. Menjawab pertanyaan seorang mahasiswa tentang hakim yang kurang profesional, dalam wawancara itu ia mengatakan: "I don't think that judges do much reading-at least, not much secondary reading. The ordinary judicial job itself requires a great

21 Posner menyebutnya dengan "Kaldor-Hics".

22 Nicholas Mercuro dan Steven G Medumo, Economic and The Law: From Posner to Post-modernism (New Jersey: Princenton University Press, 1999), hlm. 58-59.

23 Todd J. Zywicki dan Anthony B. Sanders, "Posner, Hayek, and the Economic Analysis of Law", Tanpa Tahun, hlm. 561-562. 
amount of reading. Most judges probably figure that is enough." 24

Sehingga ketika ditarik suatu benang merah, Posner pada dasarnya melihat suatu masa depan yang optimis dan percaya bahwa para hakim dapat menciptakan hukum yang baik (good law) atau pun liberal law, jika ia rajin mengabsorbsi social change dan perubahanperubahan eksternal. Tujuan pandangan posner demikian sangat jelas, yaitu terciptanya sebuah efisiensi putusan hakim yang holistik menakar seluruh aturan hukum yang menopang sistem ekonomi dan kesejahteraan sosial.

\section{Kajian Aspek Behaviorial Law and Economy dalam Bangunan Teori Hukum Richard A Posner}

Menyimak pandangan Lawrence Baum yang menegaskan ada 3 (tiga) tipe ideal perilaku pengadilan (ideal type of judicial behavior), yaitu : legal (legal), attitudinal (attitudinal), dan strategis (strategic). ${ }^{25}$ Dalam model hukum murni (pure legal model), hakim hanya menginginkan menginterpretasi hukum sebaik mungkin. Untuk alasan ini, mereka memilih antara luaran-luaran kasus alternatif dan posisi doktrinal berdasar kegunaan hukum bagi mereka. Dalam model attitudinal murni (pure attitudinal model), hakim hanya menginginkan untuk membentuk kebijakan publik yang baik (good public policy), sehingga mereka memilih antara alternatifalternatif yang berdasarkan pada kegunaankegunaannya sebagai kebijakan. Dalam model strategis paling murni (most pure strategic models), hakim berusaha untuk membuat kebijakan yang baik (to make good policy), namun mereka membatasi kebijakan yang baik dalam pengertian luaran-luaran di pengadilan dan di pemerintahan secara keseluruhan. Hakim yang tunduk pada tipe ideal legal (legal ideal type) berusaha hanya untuk membuat hukum yang baik (to make good law). Dengan ungkapan lain, hakim bertujuan menginterpretasi hukum secara akurat, tanpa memedulikan keinginan atas kebijakan yang dihasilkan.

Berbeda sedikit dengan Lawrence Baum, Richard A. Posner menegaskan bahwa peneropongan sudut pandang ekonomi terhadap hukum dalam kaca mata Posner melahirkan behaviorial law atau pun behaviorial economy. Dua kebiasaan itu kemudian tersintesis hingga melebur menjadi behaviorial of law and economy. Berkaitan dengan ini, Posner memaparkan bahwa "This (judges as future-looking rule makers) includes assessing what would be the most efficient outcome in circumstances where, because of transaction costs, a transaction would not occur without judicial intervention ${ }^{26}$. Sebagaimana konsepsi ekonomi, keberadaan biaya transaksi, bahkan dalam transaksi pemberian bantuan hukum, komponen demikian haruslah diakomodir serta diadopsi ke dalam aturan-aturan hukum positif. Biaya transaksi yang semula merupakan prinsip-prinsip ekonomi kemudian dijadikan aturan-aturan hukum dalam pengaturan pasal demi pasal agar tidak merugikan salah satu pihak dalam pelaksanaan produk perundangundangan.

Richard A. Posner, A Conversation With Judge (interview), Op.Cit., hlm. 1808.

25 Lawrence Baum, Judges and Their Audiences, A Perspective on Judicial Behavior (Princeton and Oxford, Princeton University Press, 2006), hlm. 5.

26 Todd J. Zywicki dan Anthony B. Sanders, Loc.Cit., hlm. 563. 
Prinsip behaviorial ini tampak jelas diaplikasikan dalam masyarakat yang plural, yang tidakmungkin terhindar dari biaya transaksi dalam interaksi kesehariannya. Konsekuensi selanjutnya adalah aturan hukum merupakan salah satu keharusan yang mampu memberikan kepastian hukum serta menjaga rasa keadilan sosial dalam masyarakat. Aturan-aturan hukum demikian memberikan aturan main (rule of the game) yang dapat berwujud apa saja, baik yang berbasis bahan hukum primer yang mempunyai otoritas, hingga aturan hukum yang berupa kontrak yang berlaku layaknya undang-undang bagi para pihak yang memedomaninya (pacta sunt servanda). Titik simpul dari keseluruhan pengaturan ini, tentu diarahkan demi tercapainya kesejahteraan sosial (social welfare) bagi seluas-luasnya kepentingan rakyat.

\section{E. Penutup}

\section{Kesimpulan}

Pengkajian mengenai pengawasan pemberian bantuan hukum yang dibedah menggunakan teori hukum Posner menunjukkan bahwa setiap aspek bangunan hukum Posner dapat dibuktikan keberlakuannya dalam pola pengawasan organisasi bantuan hukum di Indonesia. Penelaahan pola efisiensi pengawasan pemberian bantuan hukum, baik dari aspek heuristic, descriptive, sejarah utilitarian, wealth maximization, future consideration, maupun behaviorial law and economy, dapat diimplementasikan dalam pengawasannya. Sehingga efisiensiyang disusun, sedemikian sehingga menuju kesejahteraan sosial, menjadi titik sasaran Posner. Pandangan ke arah masa depan mengenai hakim-hakim yang memutus dengan referensi bacaan yang tinggi tanpa mengesampingkan perubahan sosial yang dinamis menumbuhkan optimisme bahwa hukum yang mensejahterakan bukan hanya isapan jempol belaka. Pada akhirnya garda terdepan disiplin ilmu hukum yang menyapa prinsip ekonomi, yang akhirnya justru terintegrasi dan terinternalisasi dalam aturan hukum merupakan keniscayaan yang menggembirakan. Oleh karenanya tidaklah mengherankan ketika pada kajian yang dikerucutkan pada pengawasan pemberian bantuan hukum dimaksud, sisi aturan hukum yang diefisienkan dengan supervisi, visitasi dan akreditasi organisasi bantuan hukum, memberi harapan besar pemenuhan kebutuhan bantuan hukum bagi masyarakat miskin dengan kulitas profesional yang menjanjikan kesejahteraan sosial.

\section{Saran}

Tulisan ini menyarankan beberapa hal sebagai berikut: pertama, Konstruksi teori hukum Posner yang menyasar kesejahteraan sosial perlu diseminasi dan disebarluaskan sebagai 'virus' yang siap mengkooptasi kejumudan pola pemikiran hakim yang hanya melulu menjadi corong undang-undang; kedua, hakim sebagai personal mulia perlu mempertimbangkan segala kelindan diskursus hukum, baik yang diutarakan penegak hukum maupun masyarakat miskin yang berhadapan dengan hukum, sudah saatnya memertimbangkan kajian teori hukum Posner berkait aspek-aspek penyusunnya; ketiga, langkah efisiensi akreditasi organisasi bantuan hukum dapat dijadikan permodelan terhadap bentuk efisiensi aturan hukum yang lain guna diarahkan bagi seluas-luas kesejahteraan social; keempat, kajian teoritik pada artikel demikian masih memerlukan pengkajian yang lebih komperhensif di tataran empirik sosiologis mengenai pandangan masyarakat atas aturan hukum yang bergerak ke arah efisiensi hukum. 


\section{DAFTAR PUSTAKA}

\section{Buku}

A. Posner, Richard, Economic Analysis of Law, Ed. 4 (USA: Harvar University Press, 1994).

A. Posner, Richard, Frontiers of Legal Theory (USA: Harvard University Press, 1994).

A. Posner, Richard, How Judges Think (Cambridge: Harvard University Press, 2008).

Hoecke, Mark van, "Legal Doctrine: Which Method(s) for What Kind of Discipline? In Mark Van Hoecke (ed.), Methodologies of Legal Research, Which Kind of Method for What Kind of Discipline" (Oxford: Hart Publishing, 2011).

Marzuki, Peter Mahmud, Penelitian Hukum (Jakarta: Kencana Prenada Media Group, 2005).

Mercuro, Nicholas and Steven G Medumo, Economic and The Law: From Posner to Post-modernism (New Jersey: Princenton University Press, 1999).

McConville, Mike and Wing Hong Chui, Ed., Research Methodfor Law (Edinburgh: Edinburgh University Press. 2007).

Lawrence Baum, Judges and Their Audiences, A Perspective on Judicial Behavior (Princeton and Oxford, Princeton University Press, 2006).

Radjagukguk, Erman, Filsafat Hukum (Modul Kuliah) (Jakarta: Universitas Indonesia, 2011).
Sulistiyono, Adi, dan Muhammad Rustamaji, Hukum Ekonomi Sebagai Panglima (Sidoarjo: Masmedia Buana Pustaka, 2009).

Yustika, Ahmad Erani, Ekonomi kelembagaan, Definisi, Teori, \& Strategi (Malang: Bayumedia Publishing, 2006).

Zywicki, Todd J. and Anthony B. Sanders, "Posner, Hayek, and the Economic Analysis of Law", Tanpa Tahun (tt).

\section{Makalah / Artikel / Prosiding / Hasil Penelitian}

Rahardjo, Satjipto, "Mengajarkan Keteraturan Menemukan Ketidakteraturan (Teaching Order Finding Disorder)" (Makalah disampaikan pada Pidato Mengakhiri Masa Jabatan Sebagai Guru Besar Tetap pada Fakultas Hukum, Universitas Diponegoro, Semarang, 15 Desember 2000).

A. Posner, Richard, "A Conversation With Judge Richard A. Posner (interview)", Duke Law Journal Vol. 58.

\section{Peraturan}

Undang-Undang Nomor 16 Tahun 2011 tentang Bantuan Hukum.

Undang-Undang Nomor 8 Tahun 1981 tentang Hukum Acara Pidana. 